\title{
Study on Coppice Management of Acacia Nilotica Tree for better Woody Biomass Production
}

\author{
Abrham Tezera Gessesse', Hailie Shiferaw Wolle ${ }^{2}$, Tesfaye T/haymanot Gezahegn ${ }^{3}$, Mesafint Minale \\ Frnta $^{4}$, Abeje Tedila Admkie ${ }^{5}$ \\ Debre Birhan Agricultural Research Center, Amhara Region Agricultural Research Institute, Debre Birhan, ETHIOPIA
}

\begin{abstract}
Over $90 \%$ of the energy consumed in the country depends on woody biomass. The rising demand for tree products and expanding population pressure resulted in decline of forest cover and consequently the demand for tree products exceeded the supply. This study was conducted at Armania Kebele with the aim of to evaluate different cutting time and management practices yielding more wood biomass volume. One indigenous tree species, preferable by the farmers, namely Acacia nilotica was selected and the experiment design in $3 \times 4$ factorial experiment with randomized complete block design arrangement and replicated three wise. Eight trees per plot were planted in two rows with 2 meter spacing. The result shows that, Acacia nilotica could be coppiced well with 13 to 29 numbers of coppices per stump at all stages of cutting time. Root collar diameter and plant height were highly correlated with growth period. Hence, Leaving of two and three number of coppices could give higher woody biomass volumes as compare to leaving one and all number of coppices and control (uncut). Therefore, it is necessary that farmers should allow two and three number coppice per stump to get high woody biomass volume for fuel-wood consumption.
\end{abstract}

Key words: Acacia, Coppicing, Biomass, nilotica

How to Cite: Gessesse AT, Wolle HS, Gezahegn TT, Frnta MM and Admkie AT. (2015) Study on Coppice Management of Acacia Nilotica Tree for better Woody Biomass Production, Malaysian Journal of Medical and Biological Research, 2(2), 91-96.

This article is is licensed under a Creative Commons Attribution-NonCommercial 4.0 International License. Attribution-NonCommercial (CC BY-NC) license lets others remix, tweak, and build upon work non-commercially, and although the new works must also
acknowledge \& be non-commercial.

\section{INTRODUCTION}

The rising demand for tree products and expanding population pressure resulted in the decline of forest cover and consequently the demand for tree products exceeded the supply. The supply of wood and woody biomass products in the North Shewa zone comes from different forest and vegetation types and production systems, including natural forests, woodlands, bushlands, community woodlots, and farm forestry. The share of the total domestic energy is: fuelwood and tree residues $70 \%$, dung $8 \%$, agricultural residues $7 \%$ and the rest comes from other sources (EFAP, 1994). Hence, $90 \%$ of the total energy is coming from biomass. The trend in North Shewa is not different from the national, especially for the lowlands. According to EFAP, 1994 report a large deficit wood has occurred since 1992 (33 million $\left.\mathrm{m}^{3}\right)$, and fuel-wood deficit amounted to 32.5 million $\mathrm{m}^{3}$. This deficit has been the main cause for the mining of forest resource base. Based on assumed per capita consumption requirements, in 1992 total requirements for wood products have been estimated to be 47.4 million $\mathrm{m}^{3}$, of which fuel wood demand was 45 million $\mathrm{m}^{3}$ (EFAP, 1994). The demand for construction poles and fence posts for construction of new houses and renovation was estimated to be 2.1 million $\mathrm{m}^{3}$. The total deficit is expected to be 84.2 million $\mathrm{m}^{3}$ by the year 2014 . Thus, being aware of these deficit alternative sources of energy, a forestation (massive plantation) program and efficient utilization and management of forest land should continue to receive attention based on research results for a greater biomass and quality production.

The existing experience of plantation species in Northern Shewa zone indicates that most species used are exotics, dominantly Eucalyptus. There is a danger in overlying on a few species. Pest or disease epidemics could wipe the entire species with devastating effects. This will become serious when there is no alternative species. Focus has given to exotic species due to the information available and their fast growth rate. However, the indigenous species have been blamed for their slow growth rate. As a general truth, for most of the indigenous species there is no information at all and some of the indigenous species are known for their slow growth rate but there are species with fast growth rate, even faster than the exotics.

Study at Sirinka agricultural research centers revealed that Acacia polyacantha produces four times more biomass than Eucalyptus camaldulensis at the end of three years growth (Yigardu 2002). Farmers also indicated their 
preference to Acacia nilotica for it produces a good charcoal and fuel wood. Moreover, survey report of the center at various weredas indicated that increasing demand for fuel-wood and the decreasing supply trend. The indigenous species which have fast growth rate also have additional desirable attributes over the exotics (e.g. termite resistance/adaptation to the environment). Wood and charcoal sale has been becoming the main stay of some farmers in Northern Shewa zone specially when there is food shortage/drought. The accessibility of some weredas to the main road made current and future wood market promising. Though farmers have their own management practices of the above mentioned indigenous species, research efforts made to improve the growth rate/performance through better management is not significant.

Acacia Nilotica occurs in woodlands and scrub in dry and moist kola agro climatic zones, 600-1700 meter a.s.1 (Azene Bekele, 2007). It is Medium to fast growing large shrub or small tree, usually $2-6 \mathrm{~m}$ but can reach $14 \mathrm{~m}$, branching from the base to make a rounded crown. Literatures indicate that Acacia nilotica do not coppice well (Tree data base CD, Azene Bekel, 2007,) but farmers in the lowlands of North Shewa say it can coppices well. Therefore, the trial was conducted with the aim of evaluating Acacia nilotica tree species for a greater woody biomass and quality production under different management regimes.

\section{Materials AND Methods}

One indigenous tree species, known for its relative fast growth rate and preferable by the farmers, namely Acacia nilotica was selected for evaluating its coppice potential. The field experiment was conducted at Armania Kebele, Tarma-Ber district, North Shewa zone and the experiment design in 3x4 factorial experiments with randomized complete block design arrangement and replicated three wise. The dimension of a plot was $6.5 \mathrm{~m}$ by $10 \mathrm{~m}\left(65 \mathrm{~m}^{2}\right)$ and eight trees per plot were planted in two rows with 2 meter spacing. At the age of three years old, four years old and five years old trees were cut close to the ground. And then after rising of sprouts from the stump Leaving one number of coppice, Leaving two number of coppice, Leaving three number of coppice and leaving all coppice per stump per cutting time were applied with one satellite control uncut trees. Growth parameters (root collar diameter, height and DBH), survival rate and fresh and dry weight data were collected.

\section{Data analysis}

Data were analyzed using SAS 9.0 followed by least significant difference (LSD) test, was applied for detecting significant differences among means.

\section{ResULt AND Discussion}

\section{Root Collar Diameter and Height}

The growth parameter result shows that root collar diameter (RCD) and height were increased by $R^{2} 98$ and 97 percent each month, respectively. The result indicated that the root collar diameter and height were highly correlated with growth period (Fig 1 and 2).

Fig. 1: Root collar diameter of Acacia nilotica at 36 months after planting

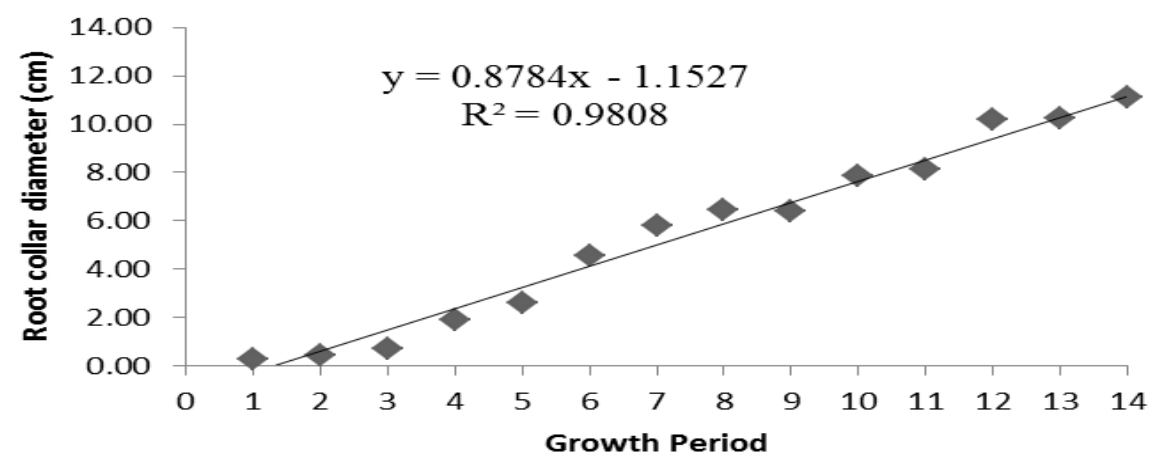

NB: $-0=0 \mathrm{MAP}, 1=3 \mathrm{MAP}, 2=6 \mathrm{MAP}, 3=12 \mathrm{MAP}, 4=15 \mathrm{MAP}, 5=24 \mathrm{MAP}, 6=30 \mathrm{MAP}, 7=36 \mathrm{MAP}, 8=42 \mathrm{MAP}, 9=48 \mathrm{MAP}$, $10=54 \mathrm{MAP}, 11=60 \mathrm{MAP}, 12=66 \mathrm{MAP}, 13=72 \mathrm{MAP}$ and $14=78 \mathrm{MAP}$ 
Fig.2: Height of Acacia nilotica at 36 months after planting

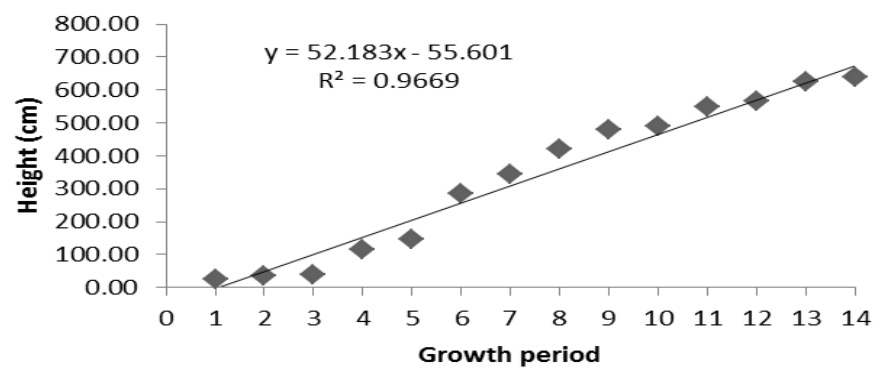

NB:-0=0MAP $, 1=3 \mathrm{MAP}, 2=6 \mathrm{MAP}, 3=12 \mathrm{MAP}, 4=15 \mathrm{MAP}, 5=24 \mathrm{MAP}, 6=30 \mathrm{MAP}, 7=36 \mathrm{MAP}, 8=42 \mathrm{MAP}, 9=48 \mathrm{MAP}$, $10=54 \mathrm{MAP}, 11=60 \mathrm{MAP}, 12=66 \mathrm{MAP}, 13=72 \mathrm{MAP}$ and $14=78 \mathrm{MAP}$

\section{Fresh and Dry Woody Biomass}

The result of dry wood biomass of Acacia nilotica ranges from 55 to 58 percent.

Fig.3: Fresh and Dry weight of Acacia nilotica

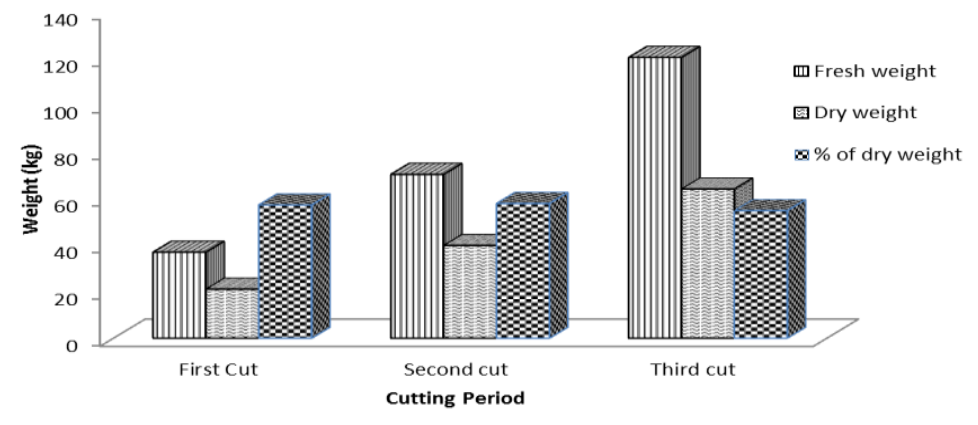

\section{Coppiced Potential and Woody Biomass Volume of Acacia nilotica}

The results of this study disproof the previous findings that say Acacia nilotica did not coppice (Tree data base CD, Azene Bekele, 1993,). However, the present study confirmed that Acacia nilotica could be coppiced well at the age of three, four and five years after planting like other coppiced tree species (Chirwa et al, 2003). From the first cutting time at the age of three years after planting, number of coppice per stump ranges from 13 to 29 and gave higher volume of woody biomass. The result of cutting period and leaving of number of coppice indicates that leaving of two coppices number of Acacia nilotica could gave higher woody biomass volumes at $36 \mathrm{MAP}$ cutting period as compare to leaving one coppice at 48MAC and leaving all coppices, three coppices and one coppice at $84 \mathrm{MAP}$ (Table 1).

Table 1: Woody biomass volume comparison of different cutting period and leaving of different number of coppice of Acacia nilotica

\begin{tabular}{|c|c|c|c|c|c|c|}
\hline \multirow{3}{*}{ Treatment } & \multicolumn{6}{|c|}{ Cutting periods } \\
\hline & \multicolumn{2}{|c|}{ 36MAP } & \multicolumn{2}{|c|}{ 48MAP } & \multicolumn{2}{|c|}{ 60MAP } \\
\hline & 48MAC m ${ }^{3} \mathrm{ha}^{-1}$ & 84MAP m ${ }^{3} \mathrm{ha}^{-1}$ & 36MAC m ${ }^{3} \mathrm{ha}^{-1}$ & 84MAP m ${ }^{3} \mathrm{ha}^{-1}$ & 24MAC m ${ }^{3} \mathrm{ha}^{-1}$ & 84MAP m ${ }^{3} \mathrm{ha}^{-1}$ \\
\hline All coppice & $4830 \mathrm{a}$ & 6190ab & $3268 \mathrm{ab}$ & $6504 \mathrm{ab}$ & $1688 \mathrm{ab}$ & $6412 \mathrm{ab}$ \\
\hline One coppice & $1412 b$ & $3013 b$ & $1387 \mathrm{~b}$ & $4518 \mathrm{~b}$ & $380 \mathrm{~b}$ & $5262 b$ \\
\hline Two coppice & $5245 a$ & $6316 a$ & $5546 a b$ & $9982 \mathrm{ab}$ & $1770 a$ & $8657 a$ \\
\hline Three coppice & $3794 \mathrm{ab}$ & $5327 \mathrm{ab}$ & $8434 a$ & $12172 a$ & $1070 \mathrm{ab}$ & $6993 a b$ \\
\hline $\mathrm{CV}$ & 49.46 & 33.55 & 51.72 & 38.65 & 69.05 & 21.39 \\
\hline
\end{tabular}

Columns with a same letter are not significantly different, MAP (months after plant), MAC (months after cutting), and CV (coefficient of variance).

On the other hand, at 48MAP the result shows that, leave three coppices can harvest $12,172 \mathrm{~m}^{3} \mathrm{ha}^{-1} \mathrm{volume}$ of woody bio-mass and followed by leaving two coppices $\left(9982 \mathrm{~m}^{3} \mathrm{ha}^{-1}\right)$ and all coppices $\left(6504 \mathrm{~m}^{3}\right.$ ha $\left.\mathrm{a}^{-1}\right)$ than leaving one coppice $\left(4518 \mathrm{~m}^{3} \mathrm{ha}^{-1}\right)$ at $84 \mathrm{MAP}$. Leaving three, two and all coppices increases the biomass yield by $169 \%, 120 \%$, and $44 \%$ respectively as compared to leaving one coppice at 84MAP. The total woody biomass volume obtained from 84 MAP by leaving two and three number of coppices had higher than leaving one coppice. 


\section{Woody biomass Volume at Coppicing Levels and Cutting Period of Acacia nilotica}

Table 2: Volume comparison of coppicing levels and cutting periods of Acacia nilotica with control

\begin{tabular}{|c|c|c|c|}
\hline \multirow{2}{*}{ Treatment } & \multicolumn{3}{|c|}{ Total woody bio-mass volume $\left(\mathrm{m}^{3} \mathrm{ha}^{-1}\right)$} \\
\hline & 84MAP (36MAP+48 MAC) & 84MAP (48MAP+36MAC) & 84MAP (60MAP+24 MAC) \\
\hline All coppice & $6190 a$ & 6504ab & 6412ab \\
\hline One coppice & $3013 a$ & $4518 \mathrm{~b}$ & $5262 \mathrm{ab}$ \\
\hline Two coppice & $6316 a$ & 9982ab & $8657 \mathrm{a}$ \\
\hline Three coppice & $5327 a$ & $12172 a$ & 6993ab \\
\hline Control (Un-cut) & $4142 a$ & $4142 b$ & $4142 \mathrm{~b}$ \\
\hline $\mathrm{CV}$ & 38.24 & 46.59 & 33.43 \\
\hline
\end{tabular}

Columns with a same letter subscription are not significantly different, MAP (months after plant), MAC (months after cutting), CV (coefficient of variance).

Woody biomass volume comparison of different coppice levels with control (uncut tree) at different cutting period result indicated that there was no significant different among coppice level treatments on woody biomass volume at 84MAP (volume at $36 \mathrm{MAP}+48 \mathrm{MAC}$ ) compared to control (Table 2). But higher volume was obtained by leaving two numbers of coppices per stump. The result indicated that, $52 \%$ higher woody biomass volume was obtained by leaving two coppices as compared to uncut (control) followed by leaving all and three coppices by $49.4 \%$ and $28.6 \%$, respectively.

Leaving three coppices of Acacia nilotica at 48MAP cutting period was obtained significantly higher woody biomass volume than as compared to uncut tree (control) at $84 \mathrm{MAP}$. Leaving three numbers of coppices at $48 \mathrm{MAP}$ was gives $12,172 \mathrm{~m}^{3} \mathrm{ha}^{-1}$ volume of woody biomass that is $193 \%$ higher than that of control (un-cut tree). Leaving two and all coppices was also increased woody biomass volume by $140 \%$ and $57 \%$ per hector as compared to uncut tree, respectively.

\section{Woody Biomass Volume at Different Cutting Periods}

The result of woody biomass volume at different cutting periods indicated that a significant difference was observed among treatments (Table 3). Cutting of Acacia nilotica at $48 \mathrm{MAP}$ and $60 \mathrm{MAP}$ periods was essential and preferable to obtain higher woody biomass volume of tree as compare to uncut tree (Harmer and Howe, 2003). The above two cutting periods could be increase woody biomass volume by $104 \%$ and $65 \%$, respectively as compared to uncut.

Table 3: Woody biomass volume at different cutting periods

\begin{tabular}{|l|l|}
\hline Treatment & Total Woody Biomass Volume at 84MAP $\mathbf{~ ( m}^{\mathbf{3}} \mathbf{h a}^{-\mathbf{1}} \mathbf{}$ \\
\hline 36 MAP (Three Years old) & $5211 \mathrm{bc}$ \\
\hline 48 MAP (Four Years old) & $8457 \mathrm{a}$ \\
\hline 60 MAP (Five Years Old) & $6831 \mathrm{ab}$ \\
\hline 84 MAP (Control) & $4142 \mathrm{c}$ \\
\hline CV & 32.86 \\
\hline
\end{tabular}

Columns with the a same letter subscriptions was not significantly different, MAP (months after plant), MAC (months after cutting), CV (coefficient of variance).

\section{Woody Biomass Volume of Different Coppice Levels}

Woody biomass of different coppice levels result indicated that significant difference was observed in treatment (Table 4). Leaving of two and three number of coppices were increased the woody biomass volume of Acacia nilotica by $200.82 \%$ and $197 \%$ respectively as compare to uncut tree

Table 4: Woody biomass volume of different coppice levels

\begin{tabular}{|l|c|}
\hline Treatment & Total Woody Biomass Volume at 84MAP $\left(\mathbf{m}^{\mathbf{3}} \mathbf{h a}^{-\mathbf{1}} \mathbf{)}\right.$ \\
\hline All coppice & $6352 \mathrm{~b}$ \\
\hline One coppice & $4264 \mathrm{c}$ \\
\hline Two coppice & $8318 \mathrm{a}$ \\
\hline Three coppice & $8164 \mathrm{ab}$ \\
\hline Un-cut (Control) & $4142 \mathrm{c}$ \\
\hline CV & 33 \\
\hline
\end{tabular}

Columns with the a same letter subscription was not significant different, MAP (months after plant), MAC (months after cutting), and CV (coefficient of variance). 


\section{Conclusion AND Recommendation}

Acacia nilotica can be coppiced well, and it is a medium to fast growing tree species, at every three months the root collar diameter and height of this tree increased by $1.5 \mathrm{~cm}$ and $100 \mathrm{~cm}$ respectively. Therefore, Cutting of Acacia nilotica tree at 36 MAP and $60 \mathrm{MAP}$ with leaving two and three number of coppices gives higher woody biomass volume and increases the woody biomass volume by $270 \%$ and by $365 \%$ respectively over leaving one number of coppice and control. Despite of the present findings on Acacia nilotica coppice management there is needs to do more research on other age of the plant in order to overcome the problems of fuelwood and other wood demand shortage in the district.

\section{ACKNOWLEDGEMENT}

This research was supported by Amhara Region Agricultural Research Institute (ARARI)

\section{REFERENCES}

Araya, A., Girma, A., \& Getachew, F. (2015). Exploring Impacts of Climate Change on Maize Yield in Two Contrasting AgroEcologies of Ethiopia. Asian Journal Of Applied Science And Engineering, 4(1), 27-37. Retrieved from http://journals.abc.us.org/index.php/ajase/article/view/Araya

Azene Bekele, 2007. Useful trees and shrubs for Ethiopia. Identification, propagation and management for 17 agroclimatic zones. world agroforestry centre, East Africa region, Nairobi, Kenya.

Chile, L., \& Talukder, D. (2014). The Paradox of Agricultural Trade Liberalization in Bangladesh and Tanzania.American Journal Of Trade And Policy, 1(1), 23-31. Retrieved fromhttp://journals.abc.us.org/index.php/ajtp/article/view/1.3

Chirwa, T. S., Mafongoya, P. L. and Chitu, K. 2003. Mixed planted fallow using coppicing and non-coppicing trees for degraded acrisols in Eastern Zambia. Journal of Agroforestry Systems 59(3): 243 - 251

Devi, K., Vijayalakshmi, P., Kumar, B., \& Talluri, V. (2014). Statistical Optimization of Kojic Acid Production through Response Surface Methodology by Aspergillus Flavus using Sago Starch Hydrolysate as a Carbon Source. Asian Journal Of Applied Science And Engineering, 3(5), 53-60. Retrieved fromhttp://journals.abc.us.org/index.php/ajase/article/view/9.6

EFAP (Ethiopian forestry action programme), 1994. Ethiopian forestry action program. Volume II. The challenges for development. EFAP secretariat, Addis Ababa, Ethiopia.

Harmer, R, and Howe, J. 2003. The silviculture and management of coppiced woodlands. Forestry Commission, Edinburgh.

Hossain, A., Khan, J., \& Miah, M. (2015). Distribution Process of Pesticides in Vegetable Production in the Southern Part of Bangladesh. Asian Business Review, 4(2), 20-24. Retrieved fromhttp://journals.abc.us.org/index.php/abr/article/view/Afjal

Hossen, S. (2015). Statistical Analysis of Current Guava Production and Its Prospect in Bangladesh. Asian Business Review, 1(1), 0914. Retrieved from http://journals.abc.us.org/index.php/abr/article/view/1.3Hossen

Ilahi, H., Saadaoui, I., Bryant, C., \& Rejeb, H. (2014). Anthropized Agrarian Landscape in the Central-west of Tunisia: Attempts to Evaluate the Production's Systems of Apples-trees Orchards in the Delegation of Sbiba. ABC Journal Of Advanced Research, 3(1), 34-43. Retrieved from http://journals.abc.us.org/index.php/abcjar/article/view/5.5

Islam, M., \& Mondal, T. (2013). Potentiality of Biomass Energy for Electricity Generation in Bangladesh. Asian Journal Of Applied Science And Engineering, 2(2), 103-110. Retrieved fromhttp://journals.abc.us.org/index.php/ajase/article/view/4.9pdf

Katsaruware, R., \& Gwembire, J. (2014). Float Trays as an Alternative to Methyl Bromide in Tobacco Production in Hurungwe District, Zimbabwe. Asian Journal Of Applied Science And Engineering, 3(2), 119-128. Retrieved fromhttp://journals.abc.us.org/index.php/ajase/article/view/6.9\%28k\%29

Mekonen, M., Tesfaye, K., \& Bayu, W. (2013). Soil Drainage and Nutrient Management to Improve Productivity of Waterlogged Vertisols for Small-scale Farmers. Engineering International, 1(2), 27-39. Retrieved from http://journals.abc.us.org/index.php/ei/article/view/2.3\%281\%29

Nahar, K. (2012). Biogas Production from Water Hyacinth (Eichhornia Crassipes). Asian Journal Of Applied Science And Engineering, 1(1), 9-13. Retrieved from http://journals.abc.us.org/index.php/ajase/article/view/1.1.12

Seid, M. (2013). Community Perception and Indigenous Adaptive Response to Climate Variability at Tehuledere Woreda, South Wollo. Engineering International, $\quad 1(2), \quad 18-26 . \quad$ Retrieved http:/ / journals.abc.us.org/index.php/ei/article/view/2.2\%281\%29

Silva, J., Nicácio, S., \& Silva, A. (2014). Work on behalf of Native Forest Conservation in the Settlements Pacas and Paraná, Murici and Girau Do Ponciano Municipalities, State of Alagoas, Northeastern Brazil. Asian Journal Of Applied Science And Engineering, 3(4), 34-40. Retrieved from http://journals.abc.us.org/index.php/ajase/article/view/8.4

Yigardu, M. 2002. Aboveground Biomass of the Dominant Tree Species on Farmlands in Sirinka Catchment, North Wollo, Ethiopia. MSc thesis, Wondo Genet Collage of Forestry and Swedish University of Agricultural Sciences, Sweden 
